\section{Australian leader pledges research boost before election}

\section{Peter Pockley, Sydney}

Australia's Conservative government facing an election by the end of this year - has announced a package that it calls the nation's largest ever boost in research funding.

Revealed late last month by Prime Minister John Howard, the plan puts an extra A $\$ 2.9$ billion (US\$1.6 billion) into research over the next five years. It was welcomed by the science lobby as a change from the years of cuts that began with the government's first budget five years ago.

With its announcement, the government largely accepted the recommendations of year-long reviews of Australia's science base and capacity for innovation (see Nature 409, 123; 2001).

The new money became available under sustained pressure from industry,

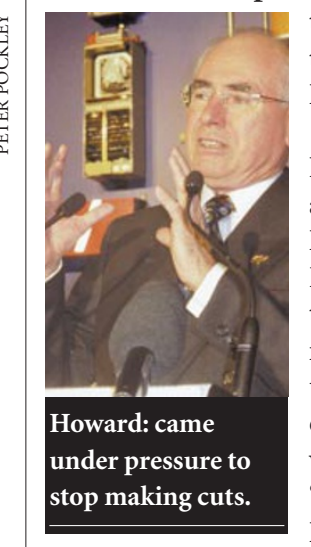
the universities and the opposition Labor Party. A week before Howard's announcement, Labor leader Kim Beazley said that the pledge to rebuild the universities and expand research would be one of "four pillars" in Labor's election campaign. He also promised to create an online university for up to 100,000 undergraduate students.

But the government's proposal will only allow for a slow phasing in of 20 programmes - half of them new which have been singled out for expansion.

The first year, beginning this July, will see research spending grow by just $3.5 \%$ from its present level of $A \$ 4.5$ billion. And the overall five-year increase amounts to less than a third of the sum the 'group of eight' leading research universities says is needed.

Universities will receive most of the new funds, through grants from the Australian Research Council, investment in infrastructure, and two new 'centres of excellence' in biotechnology and information technology. The nation's largest research agency, the Commonwealth Scientific and Industrial Research Organisation, will not get any extra money from the package.

\title{
Tissue donations slump after revelations about misuse
}

\section{David Adam, London}

Donations of human tissue for research look set to slump in the United Kingdom following revelations about the systematic misuse of human remains at a Liverpool hospital.

A pathologist at Alder Hey Hospital was found to have stripped and stored every organ from every child whose parents allowed permission for a post-mortem. In the wake of a report on the episode by the Royal Liverpool Children's Inquiry, which was published last week, other pathologists are facing a crisis of public confidence that may lead to a shortage of donated tissue for research. The political fallout from the episode has also led to the immediate suspension of some research projects, with researchers unwilling to continue until ethical and legal guidelines are clarified.

The report focuses on the actions of former Alder Hey pathologist Dick van Velzen, Professor of Foetal Infant Pathology at the hospital between 1988 and 1995. It found that van Velzen systematically ordered the unethical and illegal stripping of every organ from every child who had a post mortem.

The pathologist failed to tell parents that their children's organs would be retained. He claimed he needed the organs for research into sudden infant death syndrome, but the inquiry found that most were never used in research, or even properly examined.

Other pathologists have sought to distance themselves from his actions, but the incident has focused attention on organ collections and libraries of tissue samples held at hospitals and research centres across the country.

James Underwood, professor of histopathology at Sheffield University and vicepresident of the Royal College of Pathologists, says that fewer people have agreed to organ and tissue removal since the news about Alder Hey hit the headlines in 1999.

"The number of hospital post-mortems is down and it is becoming increasingly difficult to get certain tissue for research, particularly brain tissue," he says. This is used to study conditions such as multiple sclerosis and variant Creutzfeldt-Jakob disease (vCJD).

James Lowe, a neuropathologist at the Queen's Medical Centre in Nottingham, says tissue shortages are already damaging his efforts to monitor vCJD cases in the region. "Pathologists are no longer confident about removing brain tissue samples during postmortems," he says. "So if an elderly person with dementia falls and dies, for example, nobody is checking what disease may have caused them to fall." Lowe expects organ and tissue donation following post-mortems to

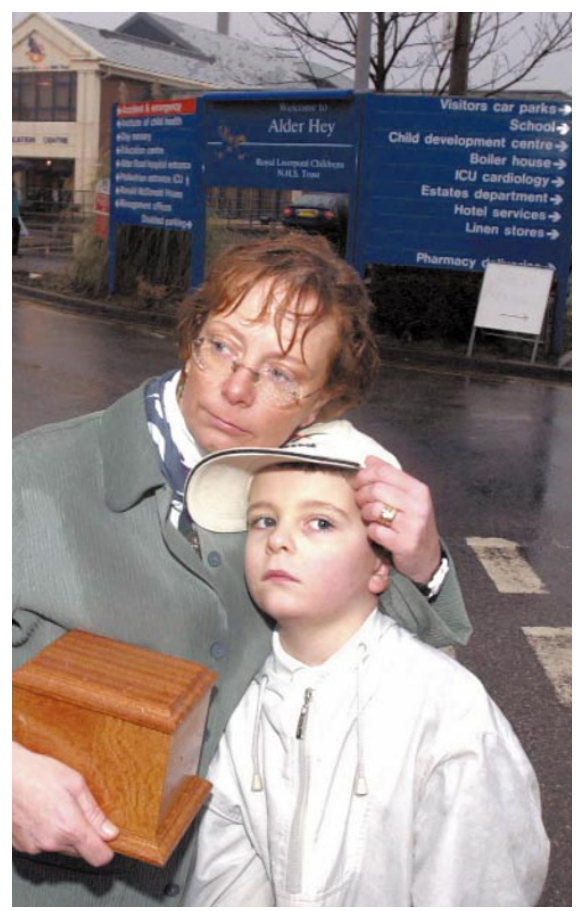

Carol Wainwright leaves Alder Hey with her son Joseph and the remains of his twin, Oliver.

drop still further. Similar declines followed recent protests about organ retention in France and Scandinavia, he notes.

In an effort to rebuild public confidence, the government is promising reforms and a stricter enforcement of existing laws. The laws allow tissues or organs to be retained after a post-mortem if relatives do not object.

Some UK pathologists say that threats of legal action are creating uncertainty even where the research uses tissue that would otherwise be destroyed, such as that removed during surgical procedures or for diagnosis.

"People have changed their attitude to tissue collection overnight," says Phil Quirke, head of histopathology at the Leeds Teaching Hospitals NHS Trust. "We are very uncertain about what we can and cannot do, so we've stopped collecting some material." His group's research into colon cancer will be "severely held up until the situation is clarified".

But president of the Pathological Society, Nicholas Wright, of St Bartholomew's Hospital, London, says Quirke is over-reacting. "I don't think there is any problem at all with using tissue excised during operations," Wright says.

Other researchers are concerned about possible restrictions on access to archived tissue, most of which was collected under older codes of ethical conduct.

http://www.rlcinquiry.org.uk

http://www.mrc.ac.uk/tissues.html 